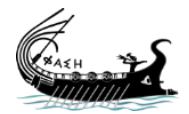

journal.phaselis.org

\section{Three New Fish Sauce Workshops Detected in Kekova Island Research}

\author{
Kekova Adası Araştırmalarında Tespit Edilen Üç Yeni Balık \\ Sosu Işliği
}

\section{Erdoğan ASLAN}

The entire contents of this journal, Phaselis: Journal of Interdisciplinary Mediterranean Studies, is open to users and it is an 'open access' journal. Users are able to read the full texts, to download, to copy, print and distribute without obtaining the permission of the editor and author(s). However, all references to the articles published in the e-journal Phaselis are to indicate through reference the source of the citation from this journal.

Phaselis: Journal of Interdisciplinary Mediterranean Studies is an international peerreviewed journal and the articles which have had their peer reviewing process completed will be published on the web-site (journal.phaselis.org) in the year of the journal's issue (e.g. Volume II: January-December 2016). At the end of December 2016 the year's issue is completed and Volume III: January-December 2017 will begin.

Responsibility for the articles published in this journal remains with the authors.

Citation E. Aslan, "Three New Fish Sauce Workshops Detected in Kekova Island Research". Phaselis III (2017) 175-185. http://dx.doi.org/10.18367/Pha.17011

Received Date: 18.05.2017 | Acceptance Date: 12.07.2017 | Online Publication Date: 24.07.2017

Editing Phaselis Research Project

www.phaselis.org 


\title{
Three New Fish Sauce Workshops Detected in Kekova Island Research
}

\author{
Kekova Adası Araştırmalarında Tespit Edilen Üç Yeni Balık Sosu İsliği
}

\author{
Erdoğan ASLAN*
}

\begin{abstract}
The production of fish products salted with fish sauces, which were among the fermented food products in the ancient age, started in the $\mathrm{VII}^{\text {th }}$ century $\mathrm{BC}$ and have since become widespread and important, especially in Spain, the Black Sea and North Africa. It was understood from the graphite on amphoras, archaeological remains and written sources that large production facilities spread across the Black Sea in the Roman period, as well as in the Western Mediterranean and the Aegean Sea. The production and trade in fish sauce, in which freed slaves commonly worked during the Roman Period, continues to exist even today despite the fact that it is practiced in different ways and methods - even centuries after the collapse of the Roman Empire. Knowledge about fish sauce production in the ancient age can be learned through ancient texts and archeological remains. The subject of this study is the contribution to the region of the fish sauce workshops found on Kekova Island - the largest Turkish island in the Mediterranean - and its vicinity, which is in the Üçă̆ız District of the Antalya province of Demre.
\end{abstract}

Keywords: Fish Sauce, Allec, Garum, Liquamen, Kekova

Öz: Antikçağ deniz ticareti ürünleri arasında da yer alan balık sosları ve diğer balık ürünleri, MÖ VII. yüzyıldan itibaren başlamış ve sonraki dönemlerde özellikle İspanya, Karadeniz ve Kuzey Afrika'da yaygınlaşarak önem kazanmışır. Büyük üretim tesislerinin Roma Dönemi'nde Karadeniz'in yanı sıra Batı Akdeniz ve Ege'de de yaygınlaştı̆̆ı, amphoralar üzerindeki grafitlerden, arkeolojik kalıntılardan ve yazılı kaynaklardan anlaşılmaktadır. Roma Dönemi boyunca daha çok azatı kölelerin meslek edindiği balık sosu üretimi ve ticareti, en yaygın olduğu Roma İmparatorluğu'nun çöküşünden sonraki yüzyıllarda ve hatta günümüzde bile farklı biçin ve yöntemlerde icra edilmesine rağmen devam etmektedir. Antikçă̆ balık sosu üretimi ile ilgili bilgilere, antik yazarlara ait yazınsal metinler ve arkeolojik kalıntılar yoluyla ulaşılabilmektedir. Bu kapsamda Antalya İli Demre illçesi Üçağız Mevkiinde bulunan ve ülkemizin Akdeniz'deki en büyük adası olan Kekova Adası ve çevresinde yapılan yüzey araştırmalarında tespit edilen balık sosu işliklerinin mimarisi, kapasiteleri ve bölge ekonomisine katkısı çalışmanın konusunu oluşturmaktadır.

Anahtar sözcükler: Balık Sosu, Allec, Garum, Liquamen, Kekova

Our surface surveys of Kekova Island and its vicinity, which is located in the Üçağız District in the province of Antalya, is still ongoing. This research has been carried out both in the urban settlements on the island and underwater beneath the shores of the island ${ }^{1}$. There are three

* Assoc. Prof., Selçuk University, Faculty of Literature, Department of Archeology, Department of Underwater Archaeology, Konya. erdoganaslan@gmail.com

1 Researches are supported by the Selçuk University Scientific Research Projects Coordinator, Research Project No: 16401066. (Araştırmalar Selçuk Üniversitesi Bilimsel Araştırma Projeleri Koordinatörlüğünün 16401066 nolu araştırma projesi tarafından desteklenmektedir.) 


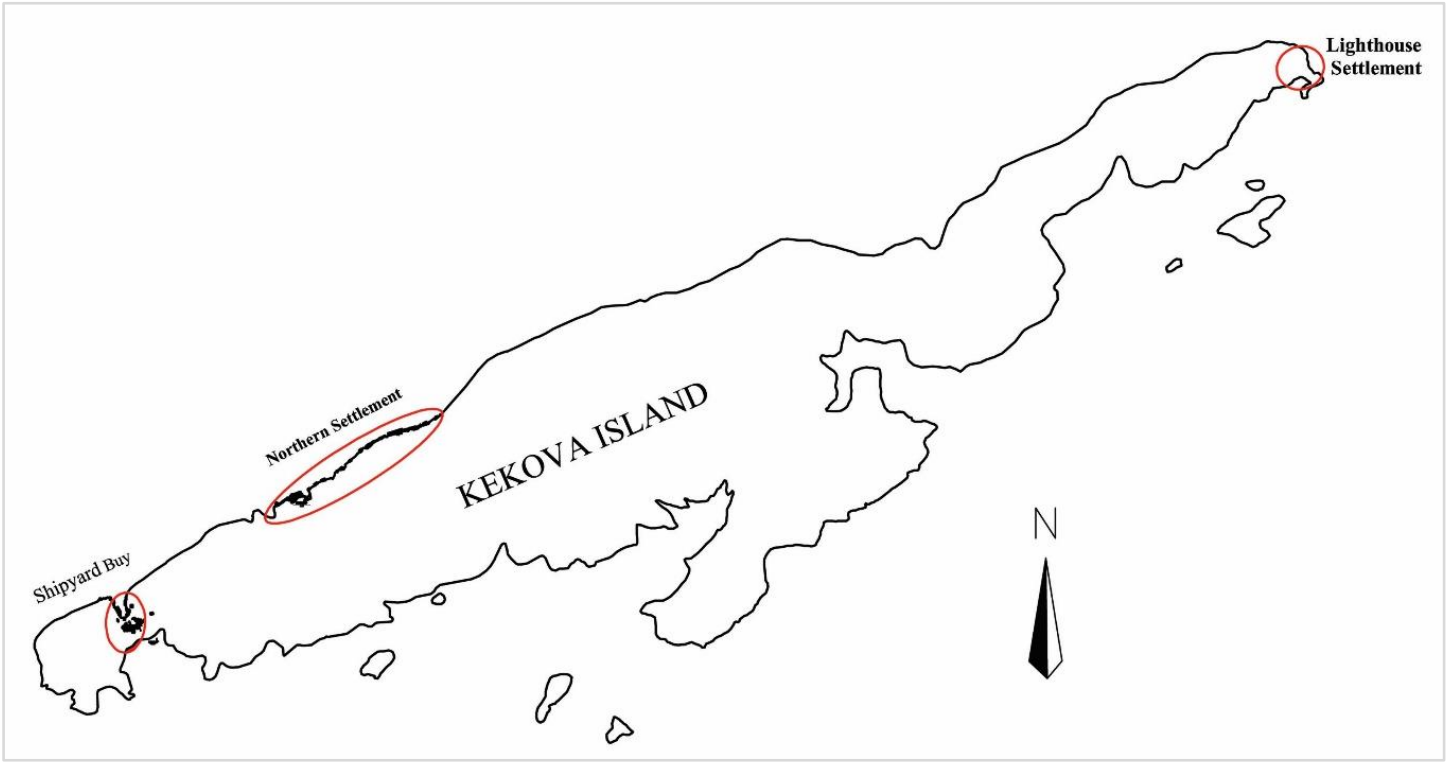

Fig. 1. Kekova Island Settlements

separate settlement areas on the island: Tersane Bay, the North Settlement and Fener Settlement (Fig. 1). In all three terrestrial settlements, there are a large number of houses, workshops, water storage tanks, churches and chapels, and a smaller number of military defense structures, watchtowers and harbor structures. In these areas, the fish sauce workshop facilities occupy a separate place and give an idea about the production economy of the island as well as the characteristic structural features, and this is the subject of the article. Six places of fish sauce production have been identified in the town of Teimiusa on the mainland opposite Kekova Island by our previous research as well as one fish sauce workshop in Tersane Bay located on the island itself; this has been shared with the world of science ${ }^{2}$. However, at the latter stages of the study, the entire island was screened and three new workshops were identified in the North Settlement area (Fig. 2). Therefore, both the fish sauce production capacity of the island and the Kekova region, and the structural characteristics of the workshops, need to be compared typologically. Our previous article on fish sauce workshops in the region is summarized below, as the production methods, varieties, historical sources, usage areas, archaeological data and significance of fish sauce have been previously and extensively discussed ${ }^{3}$.

The production of fish products salted with fish sauces ${ }^{4}$, which were among the fermented food products ${ }^{5}$ in the ancient age, started in the $\mathrm{VII}^{\text {th }}$ century $\mathrm{BC}$ and have since become widespread and important, especially in Spain, the Black Sea and North Africa ${ }^{6}$. It is understood

\footnotetext{
Aslan 2015, 141-162.

Aslan 2015, 141-145.

4 Garum, Liquamen, Allec, Muria: Foodstuffs obtained by brining various seafood with fresh water and salt. Corcoran 1963, 204; Andre 1981, 198-199; Étienne - Mayet 2002, 48; Bursa 2007, 39; Lenger 2008, 69; Atik 2008, 19; Grainger 2011, 122; Aslan 2015, 141.

5 Salsamentum or táplxos: Salted fish products. Corcoran 1963, 204; Andre 1981, 198; Curtis 2005, 31; Lenger 2008, 73.

6 Zimmerman 2003, 288; Curtis 2005, 38
} 
from the graphite on amphoras, archaeological remains and written sources ${ }^{7}$ that large production facilities spread across the Black Sea in the Roman period, as well as in the Western Mediterranean and the Aegean. The production and trade of fish sauce, in which freed slaves commonly worked during the Roman Period ${ }^{8}$, continues to exist even today ${ }^{9}$ despite the fact that it is practiced in different ways and methods ${ }^{10}$ - even centuries after the collapse of the Roman Empire ${ }^{11}$. Knowledge about ancient age fish sauce production can be learned through ancient texts ${ }^{12}$ and archeological remains ${ }^{13}$. There are different versions and different names for fish sauce - which is called trigonum in Greek - according to the fish type it is made from and the processing steps ${ }^{14}$. These names translate to salsamenta in Latin, and it is used as the general name for all fish sauces ${ }^{15}$.

A variety of information is available from ancient sources about the places where the fish sauce production workshops were located, but there is limited information on the production process. The first information on this subject dates back to a book by Archestratus in the $\mathrm{IV}^{\text {th }}$ century $\mathrm{BC}$, who recounts many of the dishes that used fish sauce, stating that there were many fish sauce workshops in Sicily and suggested that the salted fish produced there should

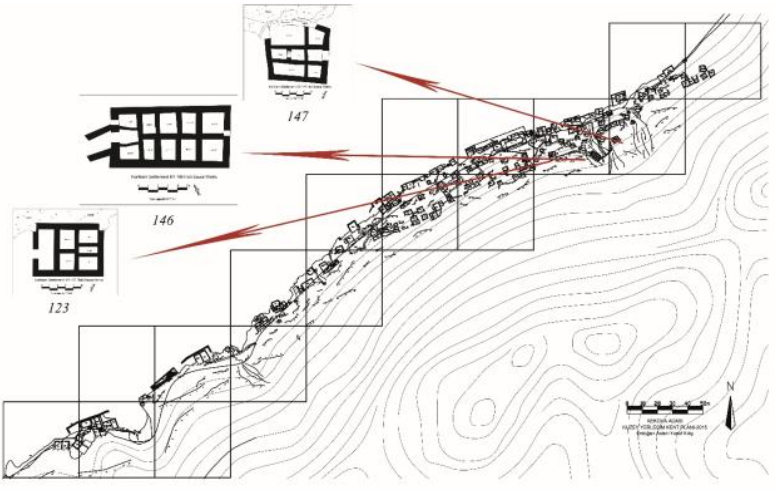

Fig. 2. North Settlement Area Plan be used in meals ${ }^{16}$. Afterwards, the book refers to some of the workshops between the $1^{\text {st }}$ century BC and the $I^{\text {st }}$ century AD in Strabon, Spain, Italy, the Black Sea and North Africa ${ }^{17}$. It is known that fish sauce was produced in Sinope, Byzantium, Clazomenai and Rhodes on the Anatolian coasts, but that is not yet supported by any physical remains ${ }^{18}$. In North Africa, it has been reported that there are a large number of salted fish production workshops in the coastal

\footnotetext{
Étienne- Mayet 2002, 7-11.

Haley 1990, 72; Étienne - Mayet 1998, 199.

Kılınç 2003, 264.

Curtis 1984, 31; Trakadas 2005, 48.

11 Chrone-Vakalopoulos - Vakalopoulos, 123.

12 Aristoph. Akh. I. 489, 970, 1250; Plaut. Capt. I. 910; Quint. Inst. VIII. 2. 3.; Galen. de Aliment. III. 30. 5; Cato de agr. XXIII. 1; LVIII. 1; LXXXVIII. 1; Var. R. III. 3.; Colum. de rust. II. 10. 16; XII. 55. 4.; Cassian. de re rust. XX. 46.; Isidor. Hisp. etym. IV. 109.; Plin. nat. IV. 370; V. 384; VI. 386; VIII. 573; XXXI. 93-95; Mart. Ep. XIII. 102103; Isidor. Hisp. etym. IV. 109; Polyb. IV. 38. 3-11.

13 Étienne 1970, 297; Mackie et al. 1971, 1; Nicolaou - Flinder 1976, 133; Curtis 1979, 5; 1983, 232; 1984, 430; 1988, 205; 1991, 1; 2005, 31; Beddows 1985, 1; Haley 1990, 72; Martin-Kilcher 1990, 37; Étienne Mayet 1991, 187; Drexhage 1993, 27; Ivanova 1994, 278; Neer - Lentacker 1994, 53; Ben Lazreg et al. 1995, 103; Cotton et al. 1996, 223; Lernau et al. 1996, 35; Ørsted 1998, 13; Desse-Berset - Desse 2000, 84; Aquerreta et al. 2001, 107; Gildberg 2004, 3; Trakadas 2004, 20; 2005, 47; Stolba 2005, 115; Wilkins 2005, 21; Neer et al. 2006, 173; Barrios 2007, 273; Berdowski 2008, 107; Lenger 2008, 69; Bernal et al. 2009, 125.

14 Curtis 2005, 35.

15 Corcoran 1963, 205; Etienne-Mayet 1991, 187 vd; Gildberg 2004, 3; Curtis 2005, 35.

16 Wilkins 1994, 2.

17 Strab. III. 1. 8; III. 4. 2; III. 4. 6; VI. 1. 1.

18 Curtis 2005, 38.
} 
settlements near the town of Zarzis in today's Tunisia, which is located in the same region as Strabon's Zuchis ${ }^{19}$. On the other hand, Polybius, in the $\|^{\text {nd }}$ century $A D$, mentioned that many food items and conserved fish products were made in the Roman and Hellenic colonies in the Black Sea ${ }^{20}$. In the $\|^{\text {nd }}$ century AD, Galenus mentioned that good-salted fish was produced on the island of Sardinia to the west of today's Italy ${ }^{21}$. The ancient sources tell us that fish workshops spread across a wide geography from Spain to the Black Sea and then to North Africa. However, looking at the data obtained as a result of archaeological excavations today, it is seen that fish sauce and salted fish workshops are found in many more settlements not included in ancient sources ${ }^{22}$. Examining the scientific studies, it is understood that the vast majority of the fish sauce workshops that were revealed by archaeological excavations were located on the shores of Spain, Portugal and Morocco ${ }^{23}$.

\section{Kekova Island Northern Settlement Research}

The second residential area on the island, called the North Settlement, is on the north-facing slope of the island. This settlement is now known as "Batık Kent (Sunken City)" by the people of the region and is located about $1 \mathrm{~km}$ from Tersane Bay on the western tip of the island. It is on the steeply sloped coastline to the east. This residential area is about $1 \mathrm{~km}$ long and is a terraced coastal settlement (Fig. 2). By terracing the main rock starting from the coastal line, with an arrangement of nine terraces on top of each other, a large number of quadrangular structures are seen consisting of one or two stories, the ground and the southern walls being completely formed by the main rock. The wooden beams for the roofs and the second floor of the constructions can still be seen today. Some of the buildings are still standing today, with cut stone blocks and rubble stones. The doors of the small number of buildings with standing fronts can be seen in-situ. The staircase carved into the main rock, rising from sea level to the upper terraces and providing access to the terraces where the structures are located, can also still be seen today. In addition, many water storage structures are among those that are still standing, especially near the staircases that reach the upper terraces. The main rock-cut channels, which feed these water storage tanks with rain water and allow the excess water to be transferred to the sea or to a lower tank after filling, and the wider, deeper channels used for sewage carved into the main rock, have also lasted to the present day. The three newly discovered fish sauce workshops in this area are detailed below.

\section{Northern Settlement KY-123 Fish Sauce Works}

The Kekova Island North Settlement Area KY-123 fish sauce workshop is located in the middle part of settlement, about 700 meters along, running parallel to the shore. The area is relatively isolated from other structures at the top of the elevated residential structures, starting at the shoreline and steeply sloping towards the terraces. In a rectangular form, with an east-west

23 Étienne 1970; Mackie et al. 1971; Nicolaou - Flinder 1976; Curtis 1979; 1983; 1984; 1988; 1991; 2005; Beddows 1985; Haley 1990; Martin-Kilcher 1990; Étienne - Mayet 1991; Drexhage 1993; Ivanova 1994; Neer - Lentacker 1994; Ben Lazreg et al. 1995; Cotton et al. 1996; Lernau et al. 1996; Ørsted 1998; DesseBerset - Desse 2000; Aquerreta et al. 2001; Gildberg 2004; Trakadas 2004; 2005; Stolba 2005; Wilkins 2005; Neer et al. 2006; Barrios 2007; Berdowski 2008; Aslan 2015. 
extension, the walls are constructed with non-rectangular blocks and mortar, and the measurements are about $9.00 \times 7.40$ meters (Fig. 3-4). The southern wall of the building is based on the section formed by cutting the main-rock. The upper structure is unprotected and the southern wall is protected to a height of 2 meters. It is understood from the slope on the wall that the construction has upper covered vaults (Fig. 5-6). The other 0.70 meter-wide walls were elevated in a sloping manner and protected to a height of about 1.50 meters. The entrance to the workshop is in the easterly direction and it is 1.30 meters wide. Entering into the workshop, there is a front room measuring $5.70 \times 2.00$ meters with 5 cetariae ${ }^{24}$ divided by walls behind this room. The largest of the differently sized cetariae has an approximate depth of 2.00 meters and is $2.75 \times 1.86$ meters in size giving a volume of $10.1 \mathrm{~m}^{3}$; the smallest one is $2.40 \times$ 0.94 meters with a volume of $4.1 \mathrm{~m}^{3}$. It is understood that the total production capacity of the workshop, along with other cetariae, is about $40.6 \mathrm{~m}^{3}$.

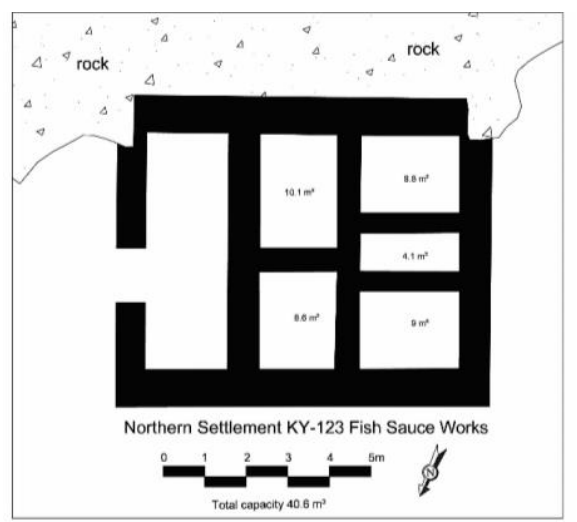

Fig. 3. Northern Settlement KY-123 Fish Sauce Works

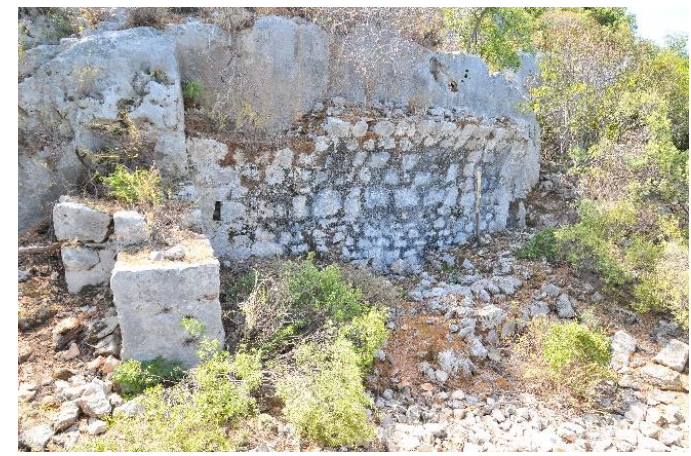

Fig. 5. KY-123 Fish Sauce Works View From North

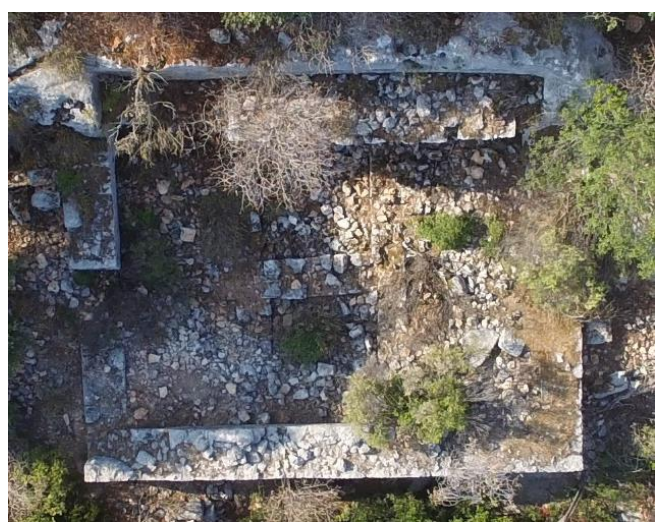

Fig. 4. KY-123 Fish Sauce Works View From Above

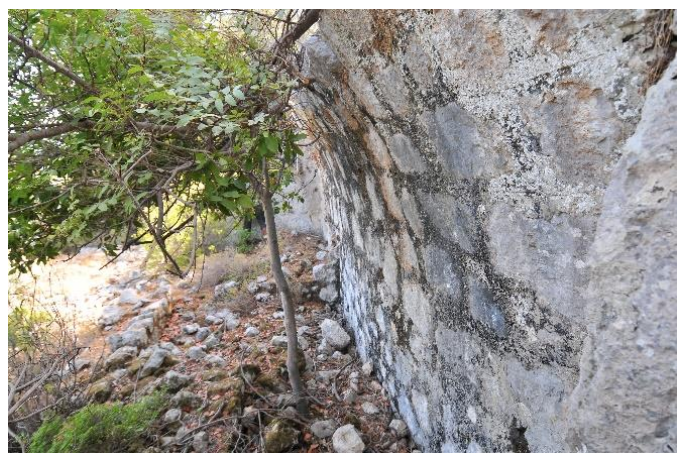

Fig. 6. KY-123 Fish Sauce Works View From West

\section{Northern Settlement KY-146 Fish Sauce Works}

On Kekova Island, the Northern Settlement Area KY-146 is located about 45 meters to the east of workshop KY-123. Also, the structure, built on the upper elevations and isolated from other structures, is found on the slope of a deep valley (Fig. 9). The rectangular structure in the northwest-southeast direction measures approximately $12.40 \times 6.70$ meters (Fig. 7-8). The roof of the structure, with walls $0.85 \mathrm{~m}$ wide and made of non-rectangular blocks and mortar, has not reached today, but the side walls are protected to a height of 3.00 meters. The collapsed

24 Cetariae: It is the Latin name of architectural cells like plastered cisterns with small square or rounded opus signinum found in fish sauce production workshops and used for sauce production. Berdowski 2013, 47. 
walls and the debris forming the upper building are scattered within the structure. A total of 10 cetariae were formed by walls in the building that were not completely rectangular (Fig. 10). In the structure, whose wall thickness is 0.70 meters, there are two window openings 0.55 meterswide in the middle of the southeastern wall to the west and directly opposite the entrance. On the long walls of the structure, there are girder holes, measuring approximately $0.15 \times$ 0.25 meters, approximately 0.30 meters above the walls that form the partitions. The entrance to the workshop faces the northwest, and two parallel walls are built diagonally to the main building to form a 3.00 meter-long corridor at the entrance. Behind this corridor there is a 1.05 meter-wide doorway. Entering into the workshop, there is a front room measuring $1.80 \times$ 1.50 meters and there are 10 cetariae divided between both sides of this room and behind the walls. The largest of the cetariae of different sizes has an approximate depth of 1.90 meters, is $2.34 \times 2.15$ meters in size and has a volume of $10.2 \mathrm{~m}^{3}$, whereas the smallest is $2.15 \times 1.08$ meters and has a volume of $4.6 \mathrm{~m}^{3}$. It is understood that the total production capacity of the workshop, along with other cetariae, was about $67.7 \mathrm{~m}^{3}$.

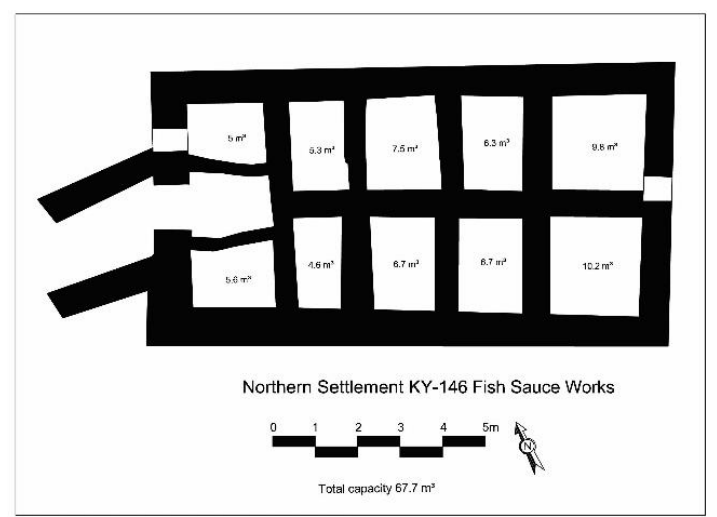

Fig. 7. Northern Settlement KY-146 Fish Sauce

Works

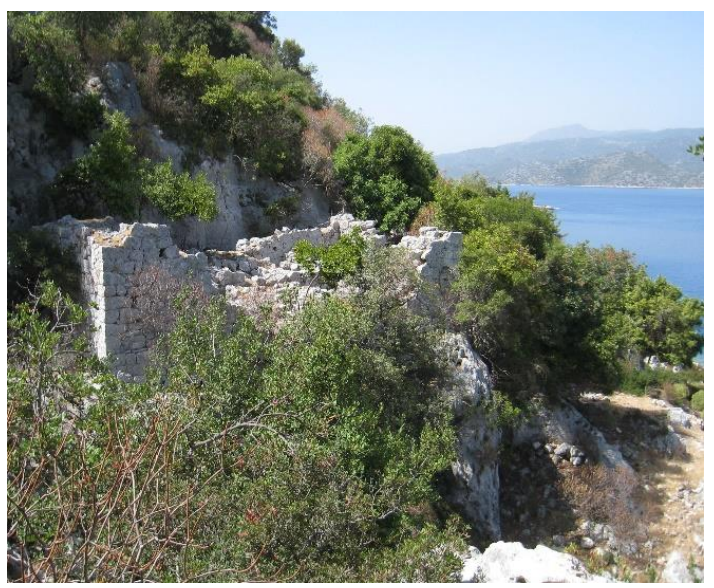

Fig. 9. KY-146 Fish Sauce Works View From East

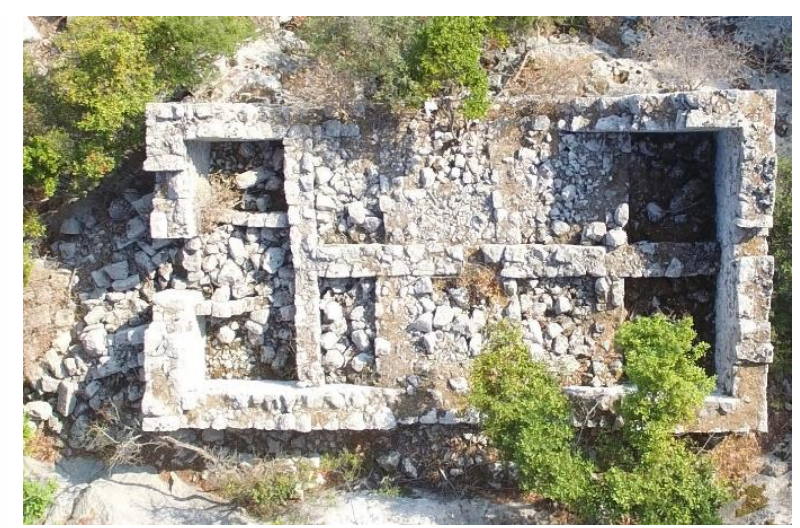

Fig. 8. KY-146 Fish Sauce Works View From Above

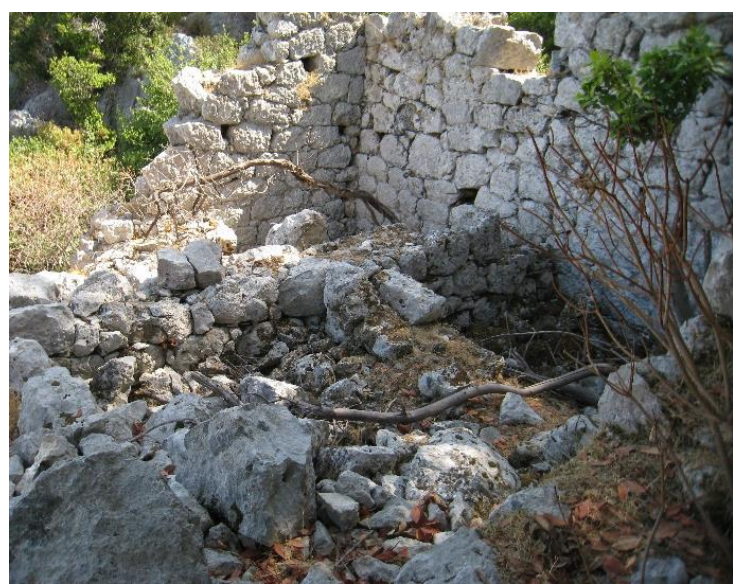

Fig. 10. KY-146 Fish Sauce Works Detail

\section{Northern Settlement KY-147 Fish Sauce Works}

The fish sauce workshop KY-147 is located about 30 meters east of the KY-146 fish sauce workshop, on the opposite side of the valley from the KY-146 workshop located on its slope. It is at the same level as the KY-146 fish sauce workshop, and it is also in an area isolated from other 
structures. In a rectangular form with an east-west extension, the walls are constructed with non-rectangular blocks and mortar, and the measurements are about $8.30 \times 7.70$ meters (Fig. 11-12). The southern wall of the building is based on the section formed by cutting the mainrock. The upper structure is unprotected, and the northern wall of 0.80 meter width is protected to a height of 2.00 meters. The 1.00 meter-wide entrance is in a westerly direction, and the door knobs and lentos have survived in-situ to the present day. Entering into the workshop, there is a front room measuring $2.00 \times 1.60$ meters and there are 6 cetariae divided between both sides of this room and behind the walls. The largest of the cetariae of different sizes has a depth of approximately 2.00 meters and is $4.80 \times 2.82$ meters in size with a volume of $27.1 \mathrm{~m}^{3}$, whereas the smallest is $1.92 \times 1.52$ meters and has a volume of $5.8 \mathrm{~m}^{3}$. It is understood that the total production capacity of the workshop, along with other cetariae, is about $68.9 \mathrm{~m}^{3}$.

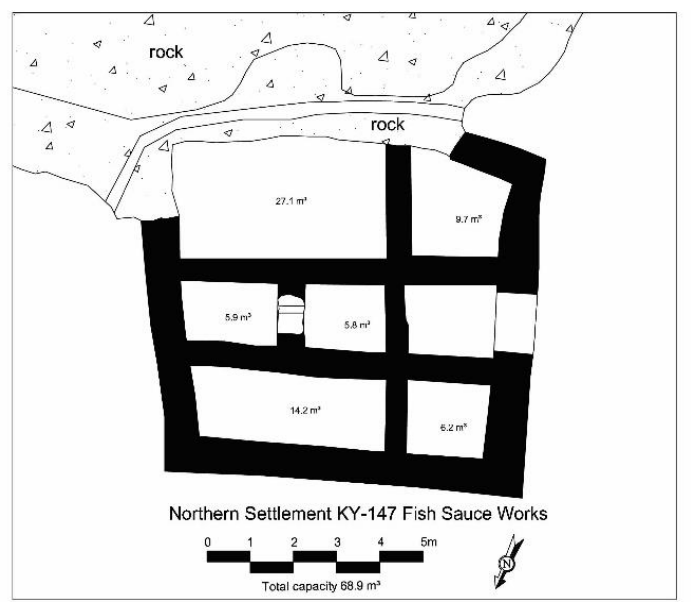

Fig. 11. Northern Settlement KY-147 Fish Sauce Works

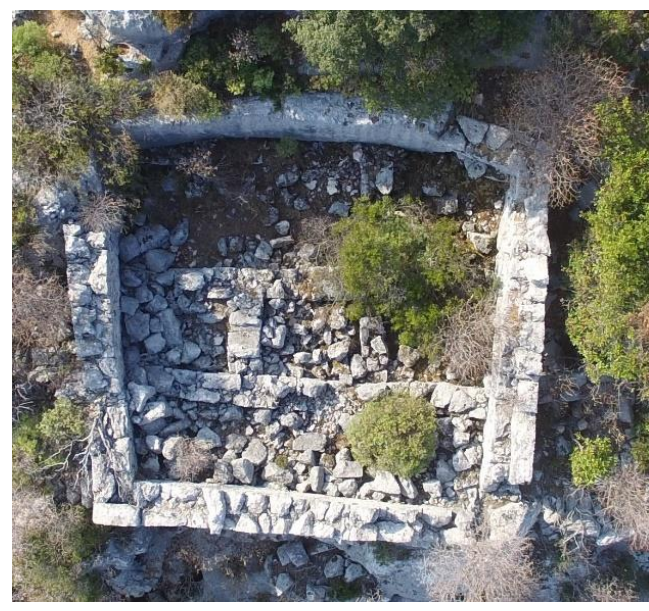

Fig. 12. KY-147 Fish Sauce Works View From Above

\section{Conclusions}

The three fish sauce workshops in Kekova Island's Northern Settlement, and their architecture ${ }^{25}$, are similar to the fish sauce workshops previously found in the area, and they were built in an area partly isolated from other settlements. It is noted that the other examples on the Mediterranean coast, which have been found during archaeological investigations, were located in a similar way ${ }^{26}$. The main reason for this is to avoid the smells formed during fermentation from disturbing city settlers. None of the upper structures of the three fish sauce workshops found in the Northern Settlement has reached today, but it is known that both the other workshops in the region, and the workshops from the coasts of Spain and Morocco, were covered with roofs. The purpose of enclosing the fish sauce workshops with a roof is to prevent the sunlight affecting the production process and to prevent the water, fish and salt mixture in the cetariae from losing water quickly, causing the product to deteriorate. In general, considering the plans of the fish sauce workshops, one or two rows of cetariae, mostly of rectangular shapes, are seen in different sizes. Some workshops are part of larger complexes, while others are independent of the city and other structures ${ }^{27}$.

The total production capacity of the seven workshops identified in the previous years in the

25 Aslan 2015, 146-153.

26 Trakadas 2005, 53-55.

27 Bezecky 1996, 329; Trakadas 2005, 47; Neer et al. 2006, 174. 
Kekova Region was estimated to be $412.7 \mathrm{~m}^{328}$. The production capacity of the three fish sauce workshops located at the Kekova Island Northern Settlement is calculated to be $177.2 \mathrm{~m}^{3}$. Therefore, with the latest findings, the total volume of fish sauce production in the region reaches a volume of $589.9 \mathrm{~m}^{3}$. It is understood that in ancient times when trade amphoras were known to carry fish sauce ${ }^{29}$, they had an average capacity of 15 liters. It was understood that the Kekova region produced enough fish sauce to fill about 40,000 amphora in a single batch. Considering that production occurred two or three times a year, it is understood how much contribution it made to the region and the city economy.

Since there were no small discoveries or inscriptions found at the time, the three fish sauce workshops located at the Kekova Island Northern Site had to be compared with other workshops in the region. They showed similarities to the Teimiusa fish sauce workshops 2 and 3 that were located in the Kekova region, in terms of the medium-sized, quadrangular-cut stone and the stone workmanship used on the walls. They also showed similarities to the stones and workmanship used during the renovation of the Kyanei Antoninus Pius Bath, and this wall work has characteristics dated to the $1 I^{\text {rd }}$ century $A D^{30}$. The Kekova Island Tersane Bay fish sauce workshop also has the same architecture and workmanship, and it is dated to the $\| l^{\text {rd }}$ century $A D^{31}$. In the three wall works of the Northern Settlement, the planning and the rubble stones used indicated a similar pattern, and further indicated that they belonged to the same period.

28 Aslan 2015, 154.

29 Almagro 50-51 amphoras, Spatheia amphoras, Mana C2 amphoras, Beltran 72 amphoras, Dressel 7-8-9-1012-38 amphoras, Pompei VII amphoras, Afrikan Tip 1-2 amphoras etc.

30 Zimmermann 2003, 290.

31 Aslan 2015, 155. 


\section{BIBLIOGRAPHY}

\section{Ancient Resources}

Aristoph. Akh.

Cassian. de re rust.

Cato de. agr.

Colum. de. rust.

Galen. de Aliment.

Isidor. Hisp. etym.

Plaut. Capt.

Plin. nat.

Polyb.

Quin. Inst

Mart. Ep.

Strab.

\section{Modern Resources}

Aquerreta et al. 2001

Aslan 2015

Atik 2008

Andre 1981

Barrios 2007

Beddows 1985
(= Aristophanes, Akharnes) Kullanılan Metin ve Çeviri: Aristophanes, The Acharnians, The Clouds, The Knights, The Wasps. Trans.: B. B. Rogers. New York 1924 (The Loeb Classical Library).

(= Cassianus Bassus, Geoponicorum Sive De Re Rustica Libri) Kullanılan Metin ve Çeviri: Cassianus Bassus, Geoponicorum Sive De Re Rustica Libri XX, Volumes 3-4. Trans.: P. Needham. Charleston 2011

(= Marcus Porcius Cato, De Agri Cultura) Kullanılan Metin ve Çeviri: Marcus Porcius Cato, On Agriculture. Trans.: W. D. Hooper. London 1934.

(= Lucius Junius Moderatus Columella, De Re Rustica) Kullanılan Metin ve Çeviri: Columella, On Agriculture. Trans.: A. B. Ash et. al. London 1941.

(Galenos, De Alimentorum Facultatibus) Kullanılan Metin ve Çeviri: Galen, On the Properties of Foodstuffs. Trans. O. Powell. Cambridge 2003.

(= Isidorus Hispalensis, Etymologiae) Kullanılan Metin ve Çeviri: Isidorus Hispalensis, The Etymologies of Isidore of Seville. Trans.: S. A. Barney et al. Cambridge 2006.

(= Titus Maccius Plautus, Captivi) Kullanılan Metin ve Çeviri: Titus Maccius Plautus, The Comedies Volume I. The Captivies (Captivi). Eds.: D. R. Slavitt P. Bovie. Trans.: R. Moore. London 1995.

(= Gaius Plinius Secundus, Naturalis Historia) Kullanılan Metin ve Çeviri: Plinius, The Historie of the World Commonly Called, The Naturall Historie of C. Plinius Secundus. Trans.: P. Holland. London 1634.

(= Polybius, The Historiai) Kullanılan Metin ve Çeviri: Polybius, The Histories. Trans.: W. R. Paton, vol. II. Cambridge - Massachusetts - London 1922 (The Loeb Classical Library).

(= Marcus Fabius Quintilianus, Institutio Oratoria) Kullanılan Metin ve Çeviri: Quintilianus, Institutio Oratoria. Trans.: E. Butler, vol. III. Domain 1920-1922 (Loeb Classical Library).

(= Martialis, Epigrammata) Kullanılan Metin ve Çeviri: Martialis, Epigrams. Trans.: C. A. Walter - M. A. Kerr, vol. II. London 1920 (Loeb Classical Library).

(= Strabon, Geographika) Kullanılan Metin ve Çeviri: Strabo, The Geography. Trans.: H. L. Jones, vol. VIII. London 1920 (Loeb Classical Library).

Y. Aquerreta, I. Astiasarán - J. Bello, "Use of Exogenous Enzymes to Elaborate the Roman Fish Sauce Garum". Journal of the Science of Food and Agriculture 82 (2001) 107-112.

E. Aslan, "Kekova Bölgesi'nde Bulunan Balık Sosu İşlikleri". CEDRUS III (2015) 141-161.

S. Atik, "Marcus Gavius Apicius ve Garum". Ankara Üniversitesi, Dil TarihCoğrafya Fakültesi Arkeoloji Bölümü Dergisi, III. ve IV. Arkeolojik Araştırmalar Sempozyumu 2 (2008) 15-25.

J. Andre, L'Alimentation et la cuisine á Rome. Paris 1981.

L. L. Barrios, "Sobre La Elaboración Del "Garum" Y Otros Productos Piscícolas En Las Costas Béticas". Mainake 29 (2007) 273-289.

C. G. Beddows, "Fermented Fish and Fish Products". Microbiology of Fer- 
Ben Lazreg et al. 1995

Berdowski 2008

Berdowski 2013

Bernal et al. 2009

Bezecky 1996

Bursa 2007

Chrone-Vakalopoulos - Vakalopoulos 2009

M. Chrone-Vakalopoulos - A. Vakalopoulos, "Fishes and Other Aquatic Species in the Byzantine Literatüre, Classification, Terminology and Scientific Names". Byzantina Symmeikta 18 (2009)123-157.

Corcoran 1963

Cotton et al. 1996

Curtis 1979

Curtis 1983

Curtis 1984

Curtis 1988

Curtis 1991

Curtis 2005

Desse-Berset - Desse 2000

Drexhage 1993

Étienne 1970

Étienne - Mayet 1991

Étienne - Mayet 1998

Étienne - Mayet 2002

Gildberg 2004

mented Foods 2 (1985) 1-39.

N. Ben Lazreg, M. Bonifay, A. Drine - P. Trousset, "Production et Commercialisation des Salsamenta de I'Afrique Ancienne". Ed. P. Trousset, Productions et Exportations Africaines. Actualitiés Archéologiques. Paris (1995) 103-142.

P. Berdowski, "Garum of Herod the Great (Latin-Greek Inscription on the Amphora from Masada)". The Qumran Chronicle 16-3/4 (2008) 107-122.

P. Berdowski, "In Search of the Lexical Meaning of the Latin Terms Cetarius and Cetaria". Eds. P. Kretschmer - F. Skutsch, Zeitsrift für Griechishe und Lateinische Sprache, Glotta 89. Göttingen (2013) 47-61.

D. Bernal, D. Cottica - A. Zaccaria , "El garum de Pompeya y Herculano (2008-2012). Síntesis de la primera campaña del proyecto hispanoitaliano". Proyectos Arqueológicos en el Exterior 2008. Madrid (2009) 125137.

Dr. Bezeczky, "Amphora Inscriptions-Legionary Supply?". Britannia 27 (1996) 329-336.

P. Bursa, Antikçă̆g'da Anadolu'da Balık ve Balıkçıık. Yayınlanmamış Doktora Tezi, İstanbul Üniversitesi, İstanbul 2007.

T. H. Corcoran, "Roman Fish Souces". The Classical Journal 58/ 5 (1963) 204-210.

H. Cotton, O. Lerenau - Y. Goren, "Fish Sauces from Herodian Masada". JRA 9 (1996) 223-238.

R. I. Curtis, "The Garum Shop of Pompeii". Cronache Pompeiane 5 (1979) 5-23.

R. I. Curtis, "In Defense of Garum". CJ 78 (1983) 232-240.

R. I. Curtis, "Salted Fish Products in Ancient Medicine". Journal of the History of Medicine and Allied Sciences 39/4 (1984) 430-445.

R. I. Curtis, "Spanish Trade in Salted Fish Products in the $1^{\text {st }}$ and $2^{\text {nd }}$ Centuries A.D.". IJNA 17 (1988) 205-210.

R. I. Curtis, Garum and Salsamenta: Production and Commerce in Materia Medica. Leiden - New York 1991.

R. I. Curtis, "Sources for Production and Trade of Greek and Roman Processed Fish. Ancient Fishing and Fish Processing in the Black Sea Region". BSS 2 (2005) 31-46.

N. Desse-Berset - J. Desse, "Salsamenta, Garum et autres Préparations de Poissons". MEFRA 112 (2000) 84-92.

H. J. Drexhage, "Garum und Garumhandel im Römischen und Spätantiken Ägypten”. MünstBeitr 12 (1993) 27-55.

R. Étienne, “À propos du garum sociorum”. Latomus 29 (1970) 297-313.

R. Étienne - F. Mayet, "Le garum à la mode de Scaurus". Eds. M. Ponsich, Le Flem - Jean Paul, Alimente 3. Madrid (1991) 187-194.

R. Étienne - F. Mayet, "Le garum à Pompei". Production et commerce, REA 100 (1998) 199-215.

R. Étienne - F. Mayet, Salaisons et souces de poisson hispaniques. Paris 2002.

A. R. Gildberg, "Enzymes and Bioactive Peptides from Fish Waste Related 
Grainger 2011

Haley 1990

Ivanova 1994

Kılınç 2003

Lenger 2008

Lernau et al. 1996

Mackie et al. 1971

Martin-Kilcher 1990

Neer - Lentacker 1994

Neer et al. 2006

Nicolaou - Flinder 1976

$\varnothing$ rsted 1998

Powell 2003

Stolba 2005

Trakadas 2004

Trakadas 2005

Wilkins 1994

Wilkins 2005

Zimmermann 2003 to Fish Silage, Fish Feed and Fish Sauce Production". Journal of Aquatic Food Product Technology 13/2 (2004) 3-11.

S. Grainger "Roman Fish Sauce: An Experiment in Archaeology". Ed. H. Saberi, Cured, Fermented and Smoked Foods, Proceedings of the Oxford Symposium on Food and Cookery 2010. Oxford (2011) 121-131.

E. W. Haley, "The Fish Sauce Trader L. Iunius Puteolanus". ZPE 80 (1990) 72-78.

N. V. Ivanova, "Fish Remains from Archaeological Sites of the Northern Part of the Black Sea Region (Olbia, Berezan)". Offa 51 (1994) 278-283.

B. Kılınç, "Balık Sosu Teknolojisi". Ege Üniversitesi Su Ürünleri Dergisi 20/12 (2003) 263-272.

D. S. Lenger, “Antikçağ’da Garum”. Arkeoloji ve Sanat 129 (2008) 69-76.

O. Lernau, H. Cotton - Y. Goren, "Salted Fish and Fish Sauces from Masada: A Preliminary Report". Archaeofauna 5 (1996) 35-41.

I. M. Mackie, R. Hardy - G. Hobbs, Fermented Fish Products. Rome 1971.

S. Martin-Kilcher, "Fischsaucen und Fischkonserven aus dem Römischen Gallien". Archäologie der Schweiz 13 (1990) 37-44.

W. V. Neer - A. Lentacker, "New Archaeological Evidence for the Consumption of Locally-produced Fish Sauce in the Northern Provinces of the Roman Empire". Archaeonautica 3 (1994) 53-62.

W. V. Neer, S. H. Dyer, R. Cappers, K. Desender - A. Ervynck, "The Roman Trade in Salted Nilotic Fish Products: Some Examples from Egypt". Documenta Archaeobiologiae 4 (2006) 173-188.

K. Nicolaou - A. Flinder "Ancient Fish-Tanks at Lapithos, Cyprus". IJNA 5/2 (1976) 133-141.

P. Ørsted, "Salt, fish and the Sea in the Roman Empire". Eds. I. Nielsen - H. S. Nielsen, Meals in a Social Context. Aspects of the Communal Meal in the Hellenistic and Roman World. Aarhus (1998) 13-35.

O. Powell, Galen. On the Properties of Foodstuffs. Cambridge 2003.

V. F. Stolba, "Fish and Money: Numismatic Evidence for Black Sea Fishing". Ed. Tønnes Bekker-Nielsen, "Ancient Fishing and Fish Processing in the Black Sea Region". BSS 2 (2005) 115-203.

A. Trakadas, "Ancient Marine Resource Exploitation in the Western Mediterranean: the Contribution of the Fishsalting Industry of Mauretania Tingitana (Morocco)". HMAP-Mediterranean Workshop, Institut de Ciències del Mar (CSIC), Barcelona, 20-22 September 2004. (2004) 1-9.

A. Trakadas, "The Archaeological Evidence for Fish Processing in the Western Mediterranean. Ancient fishing and fish processing in the Black Sea Region". BSS 2 (2005) 47-82.

J. Wilkins - S. Hill, Archestratus: The Life of Luxury. Trans.: J. Wilkins - S. Hill. Totnes 1994.

J. Wilkins, "Fish as a Source of Food in Antiquity. Ancient Fishing and Fish Processing in the Black Sea Region". BSS 2 (2005) 21-30.

M. Zimmermann, "Hafen und Hinterland. Wege der Akkulturation an der lykischen Küste. Vorbericht über die Feldforschungen in den Zentrallykischen Orten Tyberissos und Timiussa in den Jahren 1999 2001". IstMitt 53 (2003) 265-312. 